\title{
Amâncio Cardoso
}

\section{“O DESENGANO": MEDICINA ACADÊMICA E CURANDEIRISMO EM SERGIPE NO SÉCULO XIX}

\section{RESUMO}

Este artigo visa analisar um romance ambientado em Sergipe do século XIX. Trata-se de "O desengano" romance de Constantino Gomes de Souza publicado em 1871 no Rio de Janeiro. Na análise será privilegiada a relação médico/curandeiro, na qual será utilizado o método de análise do discurso para compreender a complexa relação entre esses profissionais da saúde no oitocentos, cujo paradigma teórico era sustentado pela teoria do miasma. Na obra, o personagem central, Matheus, simboliza a concretização de saberes historicamente oponentes. No entanto, a relação médico/curandeiro na obra aparece sob duas significações. A primeira, diz respeito ao conflito social entre estes terapeutas, sobretudo num regime de crescente medicalização da sociedade. E a segunda significação consiste na síntese interiorizada pelo protagonista. Nele, convivem sem exclusão o médico e o curandeiro. Esta relação idealizada na personagem central excede às convenções históricas.

Palavras-chave: Medicina acadêmica. Curandeirismo. Cólera século XIX. 


\title{
“O DESENGANO”: ACADEMIC MEDICINE AND HEALERISM IN SERGIPE IN THE 19TH CENTURY.
}

\begin{abstract}
This article aims to analyze a novel set in 19th century Sergipe. This is "O Desgano" novel by Constantino Gomes de Souza published in 1871 in Rio de Janeiro. In the analysis, the doctor / healer relationship will be privileged, in which the discourse analysis method will be used to understand the complex relationship between these health professionals in the eighties, whose theoretical paradigm was supported by the miasma theory. In the work, the central character, Matheus, symbolizes the realization of historically opposing knowledge. However, the doctor / healer relationship in the work appears under two meanings. The first concerns the social conflict between these therapists, especially in a regime of increasing medicalization of society. And the second meaning is the synthesis internalized by the protagonist. In it, the doctor and the healer live without exclusion. This idealized relationship in the central character goes beyond historical conventions.

Key words: Academic medicine; Healerism; 19th century cholera.
\end{abstract}

\section{“O DESENGANO": MEDICINA ACADÉMICA Y CURANDERISMO EN SERGIPE EN EL SIGLO XIX.}

\section{Resumén}

Este artículo tiene como objetivo analizar una novela ambientada en el Sergipe del siglo XIX. Es la novela "O Desegano" de Constantino Gomes de Souza publicada en 1871 en Río de Janeiro. En el análisis se privilegiará la relación médico/curandero, en la que se utilizará el método de análisis del discurso para comprender la compleja relación entre estos profesionales de la salud en el siglo XIX, cuyo paradigma teórico se sustentaba en la teoría del miasma. En la obra, el personaje central, Matheus, simboliza la realización de conocimientos históricamente opuestos. Sin embargo, la relación médico/curandero en la obra aparece bajo dos significados. El primero se refiere al conflicto social entre estos terapeutas, especialmente en un régimen de creciente medicalización de la sociedad. Y el segundo significado es la síntesis interiorizada por el protagonista. En él, el médico y el curandero viven sin exclusión. Esta relación idealizada en el personaje central va más allá de las convenciones históricas.

Palabras clave: Medicina académica; Curanderismo; Cólera del siglo XIX. 


\section{INTRODUÇÃO}

Este artigo visa analisar um romance ambientado em Sergipe do século XIX. Na análise do livro será privilegiado um dos eixos temáticos, qual seja: a relação médico/curandeiro abordada no volume.

Trata-se de "O desengano" romance de Constantino Gomes de Souza publicado em 1871 no Rio de Janeiro (Souza, 1871).

Constantino José Gomes de Souza nasceu em 1825 na província de Sergipe. Filho da cidade da Estância, inicia o curso de medicina na Bahia, vindo a conclui-lo no Rio de Janeiro. Termina a faculdade na Corte em 1851. Somente dois anos depois, 1853, ele defende a tese que lhe confere o grau de doutor. A demora da titulação deveu-se à falta de recursos.

Em 1855, o dr. Gomes de Souza foi designado para o torrão natal, onde a epidemia de cólera irrompeu nos últimos meses daquele ano. Por comissão do governo imperial, permaneceu na pequena província até 1857. Nela, tratou dos coléricos da vila de Santa Luzia e ficou encarregado pela quarentena do porto da cidade da Estância. Foi um dos médicos que prestou serviço em Sergipe durante os aterradores e dolorosos "tempos do cólera” de 1855.

Dr. Constantino foi romancista, dramaturgo e poeta. Como ficcionista, escreveu cinco romances: em livro - O desengano (1871) e A filha sem mãe (v. I, 1873 e v. II, 1877); em folhetins de revistas cariocas - O grumete (1873-74), Arycurana (1875-76) e O cego (187778). Na dramaturgia foi autor de quase uma dezena de peças, das quais cinco foram impressas e quase todas representadas pelo famoso ator João Caetano, no Rio de Janeiro. Como poeta publicou dois livros: Prelúdios Poéticos (1848) e Os Hymnos da Minhalma (1851).

Retornando ao Rio, prestou serviço médico na guarnição da Corte com as vantagens de $2^{\circ}$ tenente do Corpo de Saúde do Exército. Clinicou na Capital do Império e nas cidades de Macacu, Parahyba do Sul, Valença e Vassouras na província do Rio de Janeiro. Sofreu, nos últimos anos de sua vida, várias dificuldades por conta da "sedução do jogo" que o reduziu à extrema pobreza, apesar dos proventos extraídos da medicina, da colaboração para a imprensa e das obras publicadas.

Dr. Gomes de Souza veio a falecer na Corte em 1877. Faço aqui um parêntese: a data de nascimento do dr. Gomes de Souza é de 1825; verificada na Carta de médico segundo Armindo Guaraná, por isto a mantemos. Em Sacramento Blake, ela é de 1827. A data de falecimento é de 1875, conforme Liberato Bittencourt. Conservamos a de 1877, ainda seguindo Guaraná. É certo, porém, que o dr. Gomes de Souza viveu cerca de cinqüenta anos.

O romancista sergipano teve uma existência atormentada. Viveu as implicações, por um lado, de um escritor apaixonado, e por outro, de um médico ilustrado. No amor, teve experiências "amargas". Razão e paixão enrodilharam-se em seu espírito. Às virtudes da assistência ao próximo, ataram-se os vícios pelo jogo e as acres dores do amor. Sobre sua compleição, aparência e estilo de vida, um biógrafo anota: "homem robusto e alto, inteiramente descuidado de si próprio, o tipo acabado do boêmio convencido".

Abandonado em seu recanto, faleceu na miséria da solidão. Continua o seu biógrafo, morreu em "absoluta penúria, sem ter na residência nem ao menos com que se lhe fizesse o enterro". Contudo, isto é certo, Gomes de Souza se embebeu de grandes paixões em sua vida. Sejam tristes, tais as mulheres e o jogo; ou as alegres como a medicina e a literatura. Algumas, certamente, $o$ levaram à extrema pobreza material, no entanto outras lhe deixaram considerável patrimônio espiritual. (1)

\section{O ENREDO}

"O Desengano", o romance que apreciaremos, é ambientado em Estância do meado do século XIX, então uma pequena vila banhada pelos rios Piauhy e Piauhytinga.

A trama da obra assim se constitui: o jovem Matheus, belo, rico e libertino, é um dos personagens centrais. É ele, principalmente, quem dá sentido à urdidura do enredo. O pai de Matheus, um velho português, negociante usurário da região, ocupado em multiplicar seu 
capital, deixava o filho à rédea solta, entregue a todo gênero de desregramento. Sobre o jovem protagonista, nos conta o narrador: "A sua mais séria ocupação consistia em beber, fumar, jogar, seduzir as incautas donzelas e desencaminhar as pobres mulheres casadas", por outro lado ele revelava feitos de filantropia e caridade. No entanto, numa de suas investidas libertinas, Matheus tenta por todos os meios, inclusive à força, conquistar D. Izabel, uma bela e pobre senhora, esposa do carpinteiro Joaquim Rodrigues, cuja filha, Adelaide, ainda era uma criança.

Matheus contrata um comparsa para vingar a rejeição de D. Izabel às suas insistentes investidas. Eles executam um assalto a sua casa para "desonrá-la". Ao chegar em casa, seu esposo Joaquim Rodrigues, entra em luta com o amigo do libertino, sendo assassinado por este. Matheus, por outro lado, também mata seu companheiro de crime. Dona Izabel, contudo, fica com a impressão de que o "devasso" fora o autor da morte de seu marido, ao invés do comparsa, uma vez que ela se encontrava em sua alcova durante o ocorrido. Após o fato, Matheus foge para a Europa.

$\mathrm{Na}$ Europa, depois de quatorze anos, ele se forma em medicina, jurisprudência e arte. De lá, volta mudado em relação ao seu comportamento da juventude. "Amadurecera". Ao retornar para Estância, em 1849, apaixona-se por Adelaide, já uma adolescente, e por ela é correspondido, pois desconhecia o envolvimento do jovem médico com a morte de seu pai. Sua mãe, D. Izabel, tenta por todos os meios fazer com que a menina esqueça o rapaz. Com tal propósito, entrega Adelaide para ser criada e educada sob os cuidados dos padrinhos, dr. Maurício e esposa.

Pouco tempo depois, D. Izabel vem a falecer após declarar para Adelaide que esta se apaixonara pelo assassino de seu próprio pai. A jovem amarga um momento de tormento e solidão, porque não deixara de gostar de Matheus, mesmo seguindo o conselho da mãe para não se envolver com ele. Este, sem testemunha, não consegue provar sua inocência quanto à morte de Joaquim Rodrigues. Desenganado, sem poder realizar seu desejo de casamento com a adolescente, inicia um período de auto-exílio e não revela seu paradeiro. Desta forma, passa a viver por oito anos como um eremita nas matas próximas da Estância, após distribuir seus bens com os pobres e com seu fiel serviçal, Agostinho, além de deixar certo patrimônio para Adelaide.

Anos mais tarde, em 1855, a comarca da Estância é assolada pelo "flagelo do Ganges". "Estávamos na época [lamenta o narrador] sombria e calamitosa em que esse terrível viajante, (...) percorre o mundo inteiro" (Souza, 1871, p. 166). A esposa de dr. Maurício é sua primeira vítima fatal. Ele falece, meses depois, abatido pelo passamento da companheira. Assim, após a morte dos pais, Adelaide perde a madrinha para a doença reinante, e por conseguinte o padrinho, seu preceptor. Por conta desta situação, a donzela adoece gravemente. Desfalece, sendo desenganada pelo jovem doutor Justino e mais dois colegas com quem conferenciara.

A recuperação de Adelaide não é devida a este jovem médico, vindo da Bahia comissionado pelo governo imperial para cuidar das vítimas do cólera em Estância, mas antes a um certo eremita: "Era um homem alto, muito magro, de olhos grandes e vivíssimos, fisionomia atrativa e fala insinuante, apesar de ter a barba e os cabelos nimiamente crescidos e brancos como lã de algodão". Trajava uma vestimenta de peles. Ele pediu anonimato ao doutor e se dispôs a ajudar na cura da vítima, aplicando-lhe uma beberagem de "ervas do mato". Os componentes da fórmula curativa não foram reconhecidos pelo dr. Justino; uma espécie de remédio secreto. A "pobre órfâ" recobra a saúde com o milagroso lenitivo.

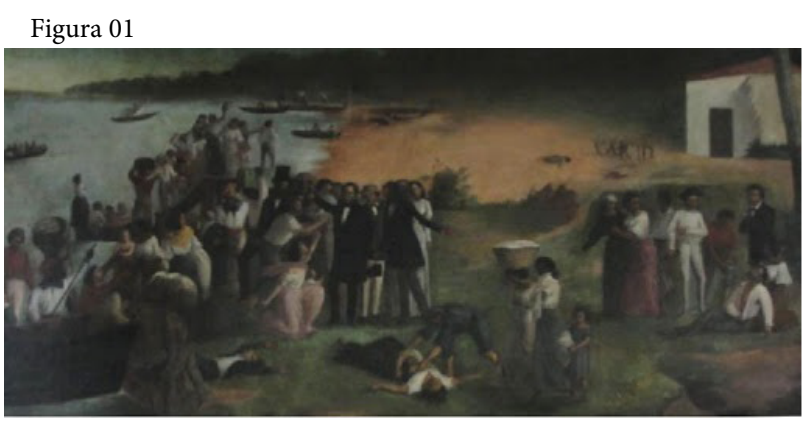

Fonte: MOTTA, Constantino Pedro Chaves da Motta (1820-1899). Cólera Morbus. c. 1858, óleo sobre tela. Altura: 157,0 cm; Largura: 335,0 cm. Col. do Museu Histórico de Cametá-PA. 
Doutor Justino, consultando a convalescente Adelaide, descobre que é filho bastardo do então doutor Matheus Soares, fruto de suas peripécias juvenis. Este, amadurecido, reaparece, anonimamente, como curandeiro das vítimas de baixo estrato social acometidas pelo cólera-morbo. Com isto, o povo lhe dá a alcunha de "curandeiro da pobreza". Numa de suas assistências, este "curandeiro" se encontra furtivamente com Adelaide, a qual ocupa seu tempo servindo de enfermeira aos humildes naquela quadra pestilenta. Ela então desconfia da identidade daquele "ancião" metido em "peles de animais".

A moléstia declinava. Finda a epidemia, a donzela resolve morar na fazenda próxima às matas. $\mathrm{O}$ "curandeiro da pobreza" ia às escondidas observá-la sem ser notado. Certo dia, foi ferido pelo punhal de um raptor que tentava desonrar a órfã. Ele retorna para a floresta ferido de morte. Adelaide, ajudada pelo "crioulo" forro Agostinho, vai ao encontro do misantropo para lhe prestar assistência. Porém, era tarde. Matheus já havia sucumbido. Fora enterrado na sua choupana. Meses depois, Adelaide falece e ali também fora sepultada por Agostinho ao lado de seu amado; lugar que não ocupara em vida.

Por fim, tem-se na trama um fio condutor explícito. Toda ela é montada para realizar o trajeto do protagonista Matheus Soares: desde sua devassa juventude, rico e libertino; passando pelo amadurecimento, com seus estudos na Europa; continuando com sua aventura de isolamento nas matas da Estância, devida ao desengano amoroso, tomando contato com ervas e raízes; até a sua morte solitária ao modo de um herói romântico.

\section{UM HERÓI ROMÂNTICO}

"O Desengano", tem veios de uma obra romântica. Seu espírito se enquadra na estética deste movimento criado na Europa no final do século XVIII. No Brasil, esta tendência foi assimilada às peculiaridades locais em meados do século seguinte. Embora tenha um caráter complexo, próprio do período contemporâneo que inaugura, é possível vislumbrar nesta corrente alguns traços singulares identificados também no romance de dr. Constantino Gomes de Souza.
Arrolemos, portanto, algumas características do romantismo também contidas na obra do escritor estanciano, para se entender como o movimento literário marca o romance representado pelo protagonista, $o$ médico/curandeiro Matheus Soares.

De início, temos no romantismo a marca do individualismo, no qual o homem se afasta da sociedade, de onde brota o senso de isolamento e uma tendência para os rasgos pessoais, o ímpeto e o desespero. Estes arroubos vincam o principal momento do romance numa guinada da trama: de devasso, Matheus se transforma, desenganado no amor, num morigerado ermitão.

Quanto à Natureza, ela era encarada pela estética romântica como imprecisa; fonte de mistério. Realidade contra a qual vai de encontro a limitação do homem. Ele a procura, então, em seus aspectos mais desordenados que, negando a ordem aparente, permitem uma visão profunda; mostra-a como algo convulso tanto no plano físico como no psíquico. Por conta disto, opondo-se ao racionalismo clássico, há a preponderância do sentimento sobre a razão. Desprezo à razão e à ciência para alcançar as potências obscuras do ser, aliado à sensação de inadaptação da vida a seus fins.

Decorre daí a associação do sentimento amoroso à idéia da morte. Amar é padecer; sofrer. Segundo o crítico literário Antônio Cândido, esta atitude denota uma sensibilidade perpassada por um "filete de tonalidade sádica e masoquista". Junte-se a isto um laivo de pessimismo e inconformismo, espécie de revolta contra os valores sociais.

O ferrete do contraste imprime na alma romântica a vocação para o desmedido e para o contraditório; fundidos por aspectos aparentemente inconciliáveis do comportamento e pelo desejo de desacordo com as normas e a rotina. O romântico é sensível à condição social dos outros homens e tem disposição para intervir a seu favor. Este humanitarismo, esta solidariedade são contrapontos do individualismo e do desejo de solidão. Como também o pessimismo é entrecortado pela utopia social e pela crença em determinado tipo de progresso inscrito no conturbado espírito romântico. 
Assim sendo, "o crime, o vício, os desvios sexuais e morais (...) tratados dramaticamente como expressões próprias do homem, tanto quanto a virtude, a temperança, e a normalidade", aumentam a complexidade deste movimento estético (Cândido, 1959, p. 22-33). Introvertidos, os românticos manifestavam as incongruências dos embates sentimentais. Nem sempre coerentes, derivavam para "atitudes paradoxais, anárquicas, oscilantes” (Moisés, 1985, p. 461-465). Tais atributos são encontrados no romance do dr. Gomes de Souza, e especialmente na personalidade do controverso e desenganado dr. Matheus.

\section{O MÉDICO E O CURANDEIRO}

Este personagem debate-se entre dois universos antinômicos. Por um lado, o médico no século XIX era associado, conforme o discurso oficial, à temperança, à normalidade, ao equilíbrio, enfim à moral burguesa vigente. Por outro, o curandeiro, sob a mesma perspectiva, ligava-se aos desvios, aos vícios, às paixões, aos excessos, por conseguinte à desordem e à barbárie (Machado, 1978, p. 196-197).

Diante desta ambivalência, a narrativa tenta uma conciliação das incongruências, numa atitude desmedida de transcender e transformar a realidade histórica. Ali, o curandeiro se "traveste" de médico humanitário e filantropo; e o médico de curandeiro de vida anônima e solitária em conluio com os saberes das matas e ervas usadas por caboclos.

Outros contrastes se operam: quando jovem Matheus era devasso, libertino, dado aos vícios; feito adulto era sóbrio, benévolo e racional. Salta, neste lapso, do vício à virtude. $\mathrm{E}$ ainda, impetuoso e desmedido, quando se isola nas matas. Cauteloso, misterioso e caridoso quando pratica as artes de curar. Assoma-se em seu âmago uma conciliação paradoxal constitutiva, como vimos, da alma romântica.

Dois aspectos da estética desta tendência merecem ser lembrados ainda para o nosso propósito: a evasão no tempo e no espaço.

A evasão no espaço se manifesta tanto pela comunhão com a natureza, de cujas respostas sua sensi- bilidade reclama, quanto pelo mergulho no seu imo místico e infinito, como se quisesse restaurar estados d'alma adormecidos no subconsciente. Numa palavra, o espectro romântico busca lugares que convidam à evocação melancólica e descobre-se, então, o encanto das vetustas sociedades ameríndias. Busca-se recuperar "o pitoresco, a cor local, o primitivo, 'o bom selvagem"'. O ermo da floresta, onde nosso herói se exila, tem um ambiente que propicia este aspecto da alma romântica, imerso na solidão, na simplicidade e nos mistérios dos saberes tradicionais sobre as "ervas milagrosas".

Quanto à evasão no tempo, ela é vivida pela sensibilidade romântica numa dimensão psicológica. Sua imaginação descortina tudo que estava perdido ou malbaratado, como as qualidades de ingenuidade, pureza, inocência, misticismo, espiritualismo e nobreza, as quais pareciam estar adormecidas nas ruínas de um “medievo do inconsciente" (Moisés, 1985, p. 465).

Estas virtudes estão espalhadas por vários personagens do romance, contudo elas se concentram no doutor e curandeiro Matheus. Tal um herói medieval, ele se aventura a enfrentar as feras da floresta; com gesto nobre, salva as vítimas do cólera; num tom místico, usa uma erva secreta; ingenuamente, auxilia o dr. Justino, dando-lhe os créditos da cura; com pureza e inocência, ama a sua donzela; espiritualista, acredita pagar as suas penas com o sofrimento de um amor desenganado. Eis aqui cinzelado o nosso sofrido herói romântico...

\section{MÉDICOS ACADÊMICOS VERSUS CURANDEIROS}

"O Desengano" foi publicado em 1871, momento crucial da história da medicina no Brasil. Após ter amargado violentas epidemias, como a de cólera-morbo de 1855-56, a classe médica e o governo imperial vinham executando um nímio processo de medicalização da sociedade. Neste processo, inclui-se a busca de profissionalização da prática médica e o reconhecimento social da medicina acadêmica. Uma das estratégias de efetivação desta política é a exacerbada perseguição dos médicos contra curandeiros. (2) 
Na primeira metade do século XIX, houve uma acentuada perseguição dos médicos acadêmicos movida contra os terapeutas populares, principalmente após a fundação das faculdades de medicina no Rio de Janeiro e na Bahia em 1832. No Brasil, se esboçava um processo de legitimação da medicina científica, na esteira do que vinha ocorrendo na Europa, intensificado pelo surgimento de devastadoras epidemias como varíola, febre amarela e cólera. Para se fortalecerem, os médicos aqui também se organizaram. Visando uma intervenção social mais ampla e independente, participaram de cargos políticos, criaram sociedades médicas, além da publicação de uma série de periódicos especializados, teses, guias práticos e dicionários populares de medicina conforme os preceitos do ensino acadêmico.

Os doutores se consideravam representantes dos princípios "racionalistas" europeus nos trópicos. Por isto, pensavam em tirar o país da barbárie implantando um projeto civilizatório com base na ideologia higienista, a qual pregava o progresso e a independência da sociedade a partir de um programa de vigilância sanitária sobre as pessoas, as instituições e os ambientes, formulando um conjunto de normas e a imposição de mecanismos para o seu funcionamento. (3)

Os charlatães eram identificados com aqueles que exerciam algum ramo da arte de curar sem título ou a devida autorização obtida por lei, como os curandeiros. Daí serem acusados pelos esculápios de cultores da não-ciência médica, dos sistemas imaginários ou das experiências não dirigidas pela razão, além de se auto-promoverem com a posse de um saber secreto, dando margem à publicidade da cura (Machado, 1978, p. 202 e passim).

A situação dos profissionais de saúde em busca de legitimidade se complica em meado do século XIX. Em 1855, o Brasil foi palco de uma das maiores epidemias de sua história com a chegada do cólera-morbo originário da Índia. O mundo se assombrava, então, com a terceira pandemia durante a qual o país foi atingido pela primeira vez.

\section{O CÓLERA NO BRASIL E EM SERGIPE}

A província do Pará foi porta de entrada da enfermidade. Em maio de 1855, a peste ancora em Belém, vinda da cidade do Porto, nos porões da galera "Defensor". Daí, o mordexim, em julho, se alastrou para a Bahia, em seguida para o Rio de Janeiro; logo após, chegou com menos intensidade ao Sul do país. No entanto, foi no Nordeste onde encontrou seu leito, atingindo toda a região. Viajando nos roteiros das vias comerciais e marítimas, a moléstia aportou sorrateira.

Após grassar por terras baianas, a epidemia aproou, em setembro, na província de Sergipe. As primeiras notícias vieram de vilas fronteiriças. A Câmara da vila de Campos (atual Tobias Barreto) deu o primeiro sinal de apelo, pois o flagelo já "devorava" com insistência algumas vítimas, e a população ensaiava um certo pânico. $\mathrm{O}$ povo e as autoridades do logradouro pediam ao governo "providências salvadoras, visto que o mal progredia com intensidade, muitas outras vítimas haviam sucumbido, e a população existia submergida em um completo desanimo, e no maior grau de terror." (Melo, 1856, p. 02).

João Gomes de Melo, o Barão de Maroim (1809-1890), assume que teve de "lançar mão de curandeiros" para alguns pontos menos populosos da província enquanto não chegavam auxílios em dinheiro, médicos, estudantes, remédios e alimentos que havia pedido ao presidente da Bahia. A prática dos curandeiros comparava-se mutatis mutandis ao ofício dos boticários, ao menos na preparação de remédios.

De acordo com a tabela das despesas gerais do relatório do Barão, entre outubro de 1855 e fevereiro de 1856, o governo provincial despendeu com "curandeiros" pelo atendimento aos coléricos a quantia de 2:515\$060; com boticários $540 \$ 000$ réis, com médicos 14:745\$000 (entre eles o dr. e escritor Gomes de Souza) e com acadêmicos 6:216\$060 (Melo, 1856, p. 04-05). Constata-se, assim, que médicos, boticários e curandeiros disputavam as diárias e aplicavam, cada um ao seu modo, os métodos de cura no tempo da peste. 
Presume-se, no entanto, que o dr. Gomes de Souza presenciara a ação desses agentes populares de cura nas vilas de Santa Luzia e Estância, em Sergipe, quando assistira os coléricos destes lugares; ou ainda durante a sua experiência clínica na Corte e cidades do interior do Rio de Janeiro. Naquela quadra pestilenta, médicos e curandeiros disputavam o mesmo proscênio.

\section{RAZÃO VERSUS BARBÁRIE?}

No romance "O Desengano", estes terapeutas também se encontram. Ali, há um diálogo travado entre o jovem doutor Justino, iniciado na medicina oficial, e "o curandeiro da pobreza". Este tentou convencer o esculápio de que seria capaz de curar a donzela Adelaide, bastando para isso saber os sintomas da enfermidade.

Doutor Justino, após perguntar-lhe se ele era médico, expressa "um sorriso de incredulidade irônica". Contudo, aceitou o auxílio do homem vestido em "peles de animais" por medo de perder a reputação com a morte de uma moça tão benquista pelo povo do lugar, embora admitindo ter por costume o bom senso de não submeter a sua "razão médica a tentativas empíricas". O outro respondeu que aquela reação irônica era "vaidade acadêmica", sendo o "orgulho humano" a causa dos seus erros mais deploráveis, e disse ainda que mais valia a experiência do que muita ciência (Souza, 1871, p. 168-169).

O autor põe em confronto visões de mundo em voga no século XIX. A razão médica, representando a "civilização"; e a experiência popular, a "barbárie". A primeira alimenta-se do descrédito da segunda como meio de legitimar-se. (4) Contudo, Matheus, personagem que transcende a realidade deste embate, serve de representação para algumas idéias sugeridas na obra.

Nele estão reunidos mundos aparentemente inconciliáveis por conta da crescente negação do discurso médico-científico sobre as formas tradicionais de saber e viver. Ele serve de síntese de uma relação conflitante no plano social: a razão científica em oposição ao empirismo popular. Porém, tal relação tem um caráter de complementaridade na figuração representada por Matheus. Ela assume, neste sentido, uma forma de oposição recíproca no plano individual.

Este personagem, a um só tempo médico formado na Europa e "curandeiro" das matas sergipenses, exemplifica uma espécie de consagração ideal da relação entre as artes de curar por ele incorporadas. Sua formação nas academias européias e a experiência junto à natureza da floresta onde passou a habitar, conferem-lhe uma árdua ambivalência e ambigüidade solucionada no plano individual. Árdua porque um cientista da segunda metade do XIX, formado em faculdades, não poderia vacilar entre um conhecimento "racional e sistemático" e outro "vulgar e empírico", correndo o risco de perder sua titulação e licença para curar com a pecha de charlatanismo.

A ambivalência presente na personagem, ao comportar valores opostos, suscita uma ambigüidade na medida em que ele encarna, em concomitância e sem exclusão, um esculápio ilustrado que, conforme os padrões vigentes, não daria razão às crenças sobrenaturais e aos remédios do povo em se tratando de saúde; e um curandeiro que em contato devoto com as forças da natureza não submeteria exclusivamente à razão científica os saberes tradicionais.

Entretanto, Agostinho, escravo forro do então Dr. Matheus, comenta que este médico e senhor, antes de se tornar "o curandeiro da pobreza", estava sempre batalhando para que o "crioulo" não acreditasse "em certas cousas, como sonhos, almas do outro mundo, encantamentos e feitiçarias,..." (Souza, 1871, p. 177).

Decerto, sua opinião deveria ser outra quando assumiu o papel de "curandeiro da pobreza". Estes componentes fantásticos seriam, em certa medida, tão importantes para o universo cultural da população em geral, quanto para um curandeiro do século XIX. Assim, percebe-se que Matheus mudou sua conduta. Ao infringir normas médicas, ele reconsidera seu saber acadêmico. Como dissera a dr. Justino: “... quase sempre mais vale a grande experiência do que a muita ciência” (Souza, 1871, p. 169). 
Portanto, no plano social a relação do "curandeiro da pobreza” com o médico, dr. Justino, é conflitante. Ao contrário, no âmbito individual ela assume uma antinomia, uma contradição recíproca. São complementares, realizando-se em síntese.

Em certo passo da obra, o médico/curandeiro assume uma postura ambivalente, própria de sua identidade. Na pele do "misterioso" ermitão ele trava um diálogo com dr. Justino. Nesta passagem, Matheus denuncia sua condição de medicastro imbuída de um imaginário de esculápio preocupado com a reputação da classe médica. Busca o anonimato para não prejudicar o jovem doutor diante da clientela. Escutemo-los:

“- Cumpre que ninguém me veja.

Por quê? pergunta o médico.

Porque não quero para mim a gloria de a ter salvado [Adelaide].

Nem eu pretendo ilustrar o meu nome com as glorias alheias.

Não digo que o doutor pretenda alardear glorias que não sejam propriamente suas; mas em bem da sua reputação, e para o crédito da classe a que pertence, cumpre que o povo não comece a assoalhar por

toda a parte que um charlatão, um feiticeiro foi quem salvou a doente." (Souza, 1871, p. 170-171).

A complexidade instalada na personagem de duplo papel está aí explicitada. Matheus, mesmo na pele do curandeiro, com sua "beberagem milagrosa", deixa sobressair o discurso de um médico. Sua humildade concorre para o reforço da política de legitimação e credibilidade do saber da medicina científica empreendida pelos doutores do XIX. Não obstante, neste caso, a reputação médica esteja calcada numa farsa, ou embuste clínico: Matheus cura Adelaide, mas o crédito é do doutor Justino.

No Império, um dos principais argumentos encetados contra os charlatães foram as denúncias feitas sobre a publicidade de suas curas a procurarem, "auri-sedentos", as glórias de seus milagres, embora mantivessem secretas as fórmulas de seus remédios. Vários foram os artigos denunciando esta prática e proibindo-a entre os médicos da Academia Imperial.

Lembremos que Adelaide foi desenganada por um diagnóstico do dr. Justino e confirmado por dois outros colegas de profissão. Diante disto, Matheus imagina, caso fosse descoberto, que sua assistência poderia ser taxada pejorativamente pelo povo de "feitiço ou charlatanismo", e se envergonharia pelo fato. Talvez esta situação também explique seu anonimato. No romance o "curandeiro" cede, em seu espírito atribulado, aos preceitos e preconceitos médicos e acadêmicos com relação à divulgação de sua arte. Ele não quer ser associado, ao menos publicamente, à superstição, à feitiçaria; em resumo, à barbárie.

Na segunda metade do século do cólera morbus, o projeto para a civilização dos costumes tem como um de seus pré-requisitos a abolição de crenças "supersticiosas" dos homens simples. A barbárie ignara precisava ser saneada pela ciência dos sábios.

Razão, ciência e verdade dos esculápios, mancomunavam-se contra a superstição, a ignorância e os vícios dos charlatães, conforme a cartilha da Academia. Era esta uma das estratégias para consolidar a medicina social, baseada na racionalidade científica, na vigilância sanitária e na legislação dos costumes. Caberia ao saber médico o poder de restabelecer a ordem, normalizar a sociedade em todos os campos, desde o político até o da moral. Era seu dever invocar o equilíbrio do organismo social e expurgar a desordem do tecido urbano. Este era o seu projeto. Para que se preservasse a saúde da população seria necessário, portanto, extirpar as paixões promotoras de vícios. Assim, se consolidaria o triunfo da "civilização" (Machado, 1978, p. 197).

Imiscuído numa relação ambígua e ambivalente, a personagem também encarna uma representação das classes e seu antagonismo (médico/curandeiro). Matheus manifesta a apropriação do saber do reprimido, ao tempo em que se alia ao espírito da repressão dos discursos da elite acadêmica. Temos, por síntese, um "bárbaro civilizado". 
No romance, o curandeiro é posto em cena como "o bárbaro civilizado", ao modo de um complexo herói romântico. Se por um lado, ainda que o apresente na figura de uma personagem descuidada com a aparência, morando no seio das brenhas, em companhia das feras, alimentando-se, como o selvagem, de frutos e de caça, bebendo água e lavando-se nas correntezas, "dormindo sobre duro grabato, vestindo-se em peles de animais"; por outro, também é penitente leitor dos manuais de medicina, arte e jurisprudência que trouxera da Europa. Além de tudo, convencera o dr. Justino no auxílio do tratamento de Adelaide "pelo sentimento de humanidade que deve sempre existir no coração do verdadeiro médico" (Souza, 1871, p. 222 e 170).

Comparado ao Cristo, o "misterioso curandeiro" tratava os desvalidos sem receber nenhuma comissão do Governo.(5) O "bárbaro" se civiliza pelos exemplos de benevolência, necessários à classe médica, como indica a personagem. Ou seja, apresenta-se-nos um médico ilustrado e um curandeiro/filantropo que salva a vida dos desvalidos gratuitamente.

Destarte, no romance, falta ao médico comissionado a caridade e a humildade; e ao curandeiro, o convívio com os costumes da burguesia emergente.(6) O primeiro se encontra afastado dos preceitos do catolicismo romano e o segundo à margem do progresso material almejado pelo discurso da medicina social difundido pelas elites ilustradas do XIX.

Matheus, em seu papel de médico e curandeiro, atendia aos princípios morais do cristianismo e aos saberes das medicinas (erudita e popular). Ele encarna a síntese e concretização de idéias antagônicas, e muitas vezes contraditórias. Pois, ao longo do século XIX, a medicina acadêmica pretendeu, cada vez mais, afastar de suas concepções a porção mágica, exótica e mística da arte de curar para garantir sua eficácia simbólica (Sampaio, 1995, p. 174-175).

Transcendência de um momento da história realizado no romance, Matheus é um exemplo de transfiguração da relação aqui tematizada, ou seja, é fruto de uma idéia que escamoteia suas raízes sociais e históricas. É, neste sentido, uma idealização da realidade: a conciliação das artes de curar acadêmica e popular.

$\mathrm{Na}$ realidade, a relação entre médicos e curandeiros na segunda metade do século XIX, foi exacerbada pela busca de legitimação de seu saber pelos primeiros e a garantia de atuação perante uma variada clientela pelos segundos, chegando a ponto de haver casos de denúncias da população de certas localidades contra os médicos e em favor de determinado curandeiro. Junte-se a isto a diversidade da clientela que recorriam aos medicastros (Pimenta, 1998, p. 367).

Os agentes populares de cura eram procurados inclusive por pacientes ricos. No romance "O Desengano", as curas dos acometidos pela moléstia reinante feitas pelo "curandeiro da pobreza" é bem aceita pelo povo, indício de que era infundado o medo de publicidade manifesta por Matheus. Ademais, apesar da alcunha, ele não curava apenas os "homens simples". Como exemplo, vejamos uma passagem em que Adelaide conversa com uma viúva pobre, a qual perdera o marido para o "terrível flagelo" e tinha três filhas acometidas que foram tratadas por Matheus, ancião curandeiro, sobre quem comentavam:

\footnotetext{
“- Esse respeitável ancião é que é o curandeiro da pobreza? (...)

É ele mesmo, minha senhora; responde a viúva.

Em vez de chamar-se o curandeiro da pobreza, diz a outra enferma, devia intitular-se antes o pae dos que padecem, porque não são somente os pobres, são também os ricos que ele tem socorrido e salvado da morte. Que o digam todos os senhores de engenho desta vizinhança." (Souza, 1871, p. 199).
}

Verifica-se acima a dualidade de Matheus, cuja vivência figura papéis antinômicos. Cura anonimamente o povo, ao contrário dos curadores de então. Age "discretamente" como a um médico era prescrito. No papel de medicastro, publica numa "memória" seus conhecimentos sobre as ervas "miraculosas". Encarna atitudes de um esculápio e modos de vida de um curandeiro. 
Na obra do doutor Constantino José Gomes de Souza, aqui analisada, encontramos outros vestígios da relação entre as medicinas de antanho. No volume do eminente sergipano, põe-se em xeque o conhecimento prático dos esculápios com relação às ervas e raízes do país. Matheus domina seus elementos e princípios ativos para a cura do cólera nos escravos e pobres livres que tratara. Ao tomar contato com a beberagem preparada pelo "eremita", o dr. Justino não reconhece as ervas ali contidas. Na narrativa, a eficácia terapêutica exercida pelo curandeiro é maior que a do jovem esculápio. Como demonstração, ouçamos um diálogo entre o doutor Justino e o ex-escravo Agostinho:

\footnotetext{
“- Alguma novidade, mestre Agostinho? pergunta o doutor.
}

Tenho uma grande porção de gente com a maldita moléstia da quadra. Mandei dar escalda-pés com cinza e beber infusão de grelos de laranjeira com laudano (7), como V. S. mandou que fizesse, logo que a moléstia aparecesse. Uns estão melhores, mas outros ... creio que esticam sempre a canela."

Escutemos agora a conversa entre Adelaide, enfermeira dos desvalidos do "tremendo flagelo", e o mesmo Agostinho. Ela pergunta:

“ - A botica está bem sortida ?...

Ainda tem muito remédio [responde Agostinho].

Não se tem repartido com a pobreza?

A pobreza não precisa de remédio de botica. Por quê?

Porque, desde que apareceu a cólera morbus por aqueles lugares, apareceu também um charlatão que a vai curando com ervas do mato e não há um só doente que ele trate, que não escape." (Souza, 1871, p. 187-189).

Vê-se, em se tomando os diálogos acima como parâmetros, escritos por um médico da academia, que os tratamentos da medicina oficial tinham menos eficácia que os tradicionais a base de ervas e raízes em geral pouco conhecidas. Algo de difícil aceitação para a influente
Academia Imperial de Medicina, cujos princípios iam de encontro com as terapêuticas informais nos tempos do cólera. (8) Parece que a eficácia de Matheus se deva ao fato de conciliar a razão científica ao empirismo tradicional.

\section{CONCLUSÃO}

O personagem de Matheus simboliza a complexa concretização de saberes historicamente oponentes. No entanto, a relação médico/curandeiro na obra aparece sob duas significações. A primeira, diz respeito ao conflito social entre estes terapeutas, suscitado pelo diálogo de Matheus e o doutor Justino, sobretudo num regime de crescente medicalização da sociedade.

A segunda significação concerne à síntese interiorizada pelo protagonista. Nele, convivem sem exclusão o médico e o curandeiro. Esta relação, na personagem, excede às convenções do contexto histórico. Matheus se obstina em acabar com a vaidade e o orgulho acadêmicos, passando a utilizar ervas e raízes dos "caboclos" e, ao mesmo tempo, conserva as doutas leituras e atitudes de um esculápio que combate o charlatanismo.

Incorpora, assim, uma identidade polissêmica, alinhavada por significados que fogem à ordem do real. $\mathrm{Ou}$ por outra, revela seus escaninhos mais profundos para realizá-la de forma ideal e complementar. Desta forma, coadunam-se na personagem valores sociais considerados inconciliáveis.

À guisa de conclusão, a relação médico/curandeiro assume na obra do doutor Constantino José Gomes de Souza duplo significado. De um lado, ela é conflituosa e paradoxal quando retratada nos diálogos de Matheus com o jovem médico. De outro, esta relação médico/ curandeiro se realiza na esfera individual de forma ambivalente e complementar, pois ele a sintetiza com eficácia, mantendo atitudes de médico, mas levando uma vida com a faina de um curandeiro.

Enfim, este personagem, de complicada sociabilidade, seja com os amigos e as amantes na juventude, ou com seus pares e a amada na maturidade, consubstancia 
idealmente, ao menos no aspecto da subjetividade, a racionalidade de um acadêmico e o empirismo de um curandeiro.

\section{REFERÊNCIAS}

CÂNDIDO, Antônio. "O Romantismo como posição do espírito e da sensibilidade”. Formação da Literatura Brasileira. São Paulo: Livraria Martins Editora, 1959.

MACHADO, Roberto; et al. Danação da norma: a medicina social e constituição da psiquiatria no Brasil. Rio de Janeiro: Edições Graal, 1978. p. 196-197.

MELO, João Gomes de. Relatório com que foi entregue a administração da província de Sergipe no dia 27 de fevereiro de 1856. Aracaju: Tipographia Official, 1856.

MOISÉS, Massaud. Dicionário de termos literários. $4^{\mathrm{a}}$ ed. São Paulo: Cultrix, 1985. p. 461-465.

SAMPAIO, Gabriela dos Reis. Nas trincheiras da cura: as diferentes medicinas no Rio de Janeiro Imperial. Campinas: Universidade Estadual de Campinas/IFCH, 1995. (Dissertação de Mestrado em História Social).

SOUZA, Constantino José Gomes de. O Desengano. Rio de Janeiro: Typ. do Apostolo, 1871. 262 p.

\section{NOTAS}

1 Sobre a biobibliografia do dr. Gomes de Souza consulte: BITTENCOURT, Liberato. Brasileiros Ilustres - I. Sergipanos Ilustres. Rio de Janeiro: Typ. Gomes Pereira, 1913. p. 33-35; CARNEIRO, José de Magalhães. Panorama Intelectual de Sergipe. Aracaju: Imprensa Oficial, 1940. p. I-III; SACRAMENTO BLAKE. Diccionario Bibliographico Brazileiro. Rio de Janeiro: Imprensa Nacional, 1893. v. 2. p. 138-139; GUARANÁ, Manoel Armindo Cordeiro. Diccionario bio-bibliographico sergipano. Rio de Janeiro: Pongetti, 1925. p. 56-57; ARAÚJO, Acrísio Torres. Literatura sergipana. Aracaju: s.n., 1972. p. 17-18; LIMA, Jackson da Silva. História da Literatura Sergipana. Aracaju: Fundesc, 1986. v. 2. p. 79-135; SAMPAIO, Prado. A Literatura Sergipana. Maroim/SE: Imprensa Econômica de Gouvêa \& Ca.., 1908. p. 31-32.

2 Sobre o estabelecimento de entidades de caráter científico no Brasil, entre elas as de medicina, a partir dos anos de 1870, ver: SCHWARCZ, Lilia M. "Entre 'Homens de Sciencia". In O espetáculo das raças: cientistas, instituições e questão racial no Brasil - 1870-1930. São Paulo: Companhia das Letras, 1993. p. 23-42.

3 Entende-se por "medicalização" o conjunto de mecanismos para a construção e intervenção na sociedade de um saber médico sistematizado. Este saber, conhecido por medicina social, nasceu na Europa no início do século XIX, cujos princípios estabelecem o controle e vigilância do indivíduo, da população, das instituições e dos espaços através da dilatação de sua influência em áreas como o direito, a moral, a política, e a economia, mantendo uma forte relação com o Estado.
Enfim, este processo, o da medicalização, atribui à medicina o poder de ordenar e disciplinar o corpo social à luz do seu discurso como verdade científica, logrando o equilíbrio e o progresso em marcha para a "civilização". Cf. FOUCAULT, M. "O nascimento da medicina social”. In Microfísica do poder. 12 ed. Rio de Janeiro: Graal, 1996. p. 79-98. Para o conhecimento das políticas de implantação da medicina social no Brasil, ver: MACHADO, R. et al. "Parte II: Melhor prevenir que remediar". Danação da normal. Rio de Janeiro: Graal, 1978. p. 153-372.

4 Para entender o conceito de "civilização" e "barbárie" no universo epistemológico de um médico e historiador do século XIX, ver: ALVES, Francisco José. A marcha da civilização: Uma leitura da historiografia de Felisbelo Freire. Rio de Janeiro: UFRJ/IFCS, 1998. (Tese de doutorado em História Social).

5 Sobre "o curandeiro da pobreza" o narrador comenta: “... esse grande homem que à semelhança do Cristo ía de choupana em choupana distribuindo pelos enfermos e desvalidos o bálsamo e o pão celeste da caridade". SOUZA, Constantino José Gomes de. O desengano. Rio de Janeiro: Typ. do Apostolo, 1871. p. 193.

6 Para conhecer alguns traços da cultura material e da emergência de um modo de vida burguês (comportamentos da ideologia que delimita as fronteiras entre o público e o privado, valorizando o individualismo, o universo familiar, a acumulação de capital real e simbólico, o consumo e a ascensão social) no âmbito do cotidiano das elites no Rio de Janeiro Imperial, ver: LIMA, Tânia Andrade. "Humores e odores: ordem corporal e ordem social no Rio de Janeiro, século XIX”. História, Ciências e Saúde-Manguinhos. Rio de Janeiro, v. II, n. 03, nov. 1995/fev. 1996. p. 44-96.

7 "Laudano (de Sydenham) - Laudanum em latim. Esta palavra vem de laus, louvor, como para designar um medicamento que merece grandes elogios. O de Sydenham, em porções ou em clísteres, serve como calmante. Sua composição contém ópio, canela, açafrão e cravo da Índia pela maceração em vinho de Málaga”. In CHERNOVIZ, Pedro Luiz Napoleão. Diccionario de medicina popular. 6 ed. Paris: A. Roger \& F. Chernoviz, 1890. v. II. p. 286.

8 "No cólera": expressão colhida e anotada pelo "garimpeiro" do folclore sergipano, Carvalho Deda. Esta forma de datação popular foi encontrada no interior de Sergipe cem anos após a manifestação da epidemia. Ela serve para designar a fixação de uma determinada época (meados do século XIX) ou data específica (1855-56), relativas ao fenômeno que vincou o imaginário coletivo. Tal expressão é a síntese de "no tempo do cólera-morbo de 1855.... Cf. DEDA, Carvalho. Brefáias e burundangas do folclore sergipano. Aracaju: Livraria Regina, c. 1965. p. 197.

\section{O AUTOR}

Amâncio Cardoso

É Mestre em História, professor dos cursos de Turismo do IFS- acneto@infonet.com.br. Orcid: 3436-3368-4974-8221. 